\begin{tabular}{c} 
Efficient Vol 2 (3) (2019): 512 -523 DOI: https://doi.org/10.15294/efficient.v2i3.35904 \\
$\begin{array}{c}\text { Indonesian Journal of Development Economics } \\
\text { https://journal.unnes.ac.id/sju/index.php/efficient }\end{array}$ \\
\hline
\end{tabular}

\title{
Aquaculture Production Optimization Model of Brebes Regency
}

\author{
Diah Safitri $^{1 \bowtie}$, Sucihatiningsih Dian Wisika Prajanti ${ }^{2}$ \\ Jurusan Ekonomi Pembangunan, Fakultas Ekonomi, Universitas Negeri Semarang \\ Permalink/DOI: https://doi.org/10.15294/efficient.v2i3.35904
}

Received: Juny 2019; Accepted: September 2019; Published: December 2019

\begin{abstract}
The purpose of this study was to determine the combination of aquaculture production in Brebes District and to know the intervals that might occur in variables so that the optimization model can still be used. The research variable consists of decision variables, namely the amount of aquaculture commodities that must be produced to achieve maximum profit. The commodities in question are shrimp, tilapia, catfish, milkfish, and seaweed. The constraint variable is the production factor used in aquaculture activities, including land, seeds, feed and fertilizer, and operational costs. The method of data analysis in this study uses Linear Programming analysis and sensitivity analysis. The type of data used is primary data from interviews with aquaculture households in Brebes District. The results showed the maximum profit from aquaculture production in Brebes District can be obtained when the number of vaname shrimp produced was 975,383.5 $\mathrm{kg}$, catfish as much as $1,985,898 \mathrm{~kg}$, milkfish as much as $885,986.6 \mathrm{~kg}$, and seaweed as much as 2,532,448 kg. From the combination of aquaculture production, it can be seen that the maximum amount of profit obtained is Rp. 111,590,500,00o for one cultivation cycle. Suggestions: 1) strengthen the institutional household of aquaculture. 2) The government is expected to provide direction and incentives to cultivation FHs related to achieving production combination targets that produce maximum profits. 3) In the future, it is hoped that the related offices can have a more complete database on the fisheries sector, so that the analysis carried out has accurate results.
\end{abstract}

Keywords: Production, Optimization, Aquaculture

\begin{abstract}
Abstrak
Tujuan penelitian ini adalah mengetahui kombinasi produksi perikanan budidaya di Kecamatan Brebes serta mengetahui intervalperubahan yang mungkin terjadi pada variabel sehingga model optimasi masih dapat digubakan. Variabel penelitian terdiri dari variabel keputusan yaitu jumlah komoditas perikanan budidaya yang harus diproduksi untuk mencapai keuntungan maksimal. Adapun komoditas yang dimaksud adalah udang, nila, lele, bandeng, dan rumput laut. Variabel kendala adalah faktor produksi yang digunakan dalam kegiatan budidaya, diantaranya adalah lahan, bibit, pakan danpupuk, dan biaya operasional. Metode analisis data dalam penelitian ini menggunakan analisis program linear dan analisis sensitivitas. Jenis data yang digunakan adalah data primer dari hasil wawancara dengan rumah tangga perikanan budidaya di Kecamatan Brebes. Hasil penelitian menunjukkan euntungan maksimal dari produksi perikanan budidaya di Kecamatan Brebes dapat diperoleh ketika jumlah udang vaname yang diproduksi sebanyak 975.383,5 kg, lele sebanyak $1.985 .898 \mathrm{~kg}$, bandeng sebanyak $885.986,6 \mathrm{~kg}$, dan rumput laut sebanyak $2.532 .448 \mathrm{~kg}$. Dari kombinasi produksi perikanan budidaya tersebut, dapat diketahui jumlah keuntungan maksimum yang diperoleh sebesar Rp. 111.590.500.0oo untuk satu siklus budidaya. Saran: 1) memperkuat kelembagaan rumah tangga perikanan budidaya. 2) Pemerintah diharapkan memberikan arahan dan insentif kepada RTP budidaya terkait pencapaian target kombinasi produksi yang menghasilkan keuntungan maksimum. 3)Kedepannya diharapkan dinas terkait dapat memiliki database mengenai sektor perikanan yang lebih lengkap, sehingga analisis yang dilakukan memiliki hasil yang akurat.
\end{abstract}

\section{Kata Kunci: Produksi, Optimasi, Akuakultur}

How to Cite: Safitri, D., \& Prajanti, S. (2019). Aquaculture Production Optimization Model of Brebes Regency. Efficient: Indonesian Journal of Development Economics, 2(3), $512-523$. https://doi.org/10.15294/efficient.v2i3.35904

(C) 2019 Semarang State University. All rights reserved

\footnotetext{
Alamat Korespondensi :

Alamat: Gedung L2 Lantai 2 FE Unnes

Kampus Sekaran, Gunungpati, Semarang, 50229

E-mail : diahsafitri777@gmail.com
}

ISSN 2655-6197 


\section{INTRODUCTION}

Meeting the needs of fish globally can not be realized if it only depends on the capture fisheries sector. Aquaculture as an alternative solution to realize the fulfillment of the needs of fisheries commodities is required to grow more than doubled in the mid-21st century. Aquaculture production in 2012 amounted to 67 million tons, where in 2050 production is expected to reach 140 million tons (Waite, et al., 2014). Indonesia is one of the countries that produce capture and aquaculture commodities.

Aquaculture production in Indonesia is always higher than capture fisheries production. This supports aquaculture as an alternative solution to meet the needs of national fisheries commodities. Below is a table of national capture fisheries and aquaculture production:

Table 1. National Capture Fisheries and Aquaculture Production in 2014-2017 (million tons)

\begin{tabular}{llll}
\hline Year & Captur Fisheries & Aquaculture & Total \\
\hline 2014 & 6,48 & 14,36 & 20,84 \\
2015 & 6,52 & 15,63 & 22,15 \\
2016 & 6,83 & 16,68 & 23,51 \\
2017 & 6,04 & 17,22 & 23,26 \\
\hline
\end{tabular}

Source: KKP (2018)

Table 1 shows that aquaculture production in Indonesia is more than doubled capture fisheries production. In line with this, aquaculture production in Central Java Province is also higher than capture fisheries production. Below is a table showing the capture fisheries and aquaculture production in Central Java Province in 2013-2016:
Table 2. Capture Fisheries and Aquaculture Production in Central Java Province in 20132016 (Tons)

\begin{tabular}{lll}
\hline Year & Aquaculture & Capture Fisheries \\
\hline 2014 & 501.809 & 261.017 \\
2015 & 421.022 & 352.617 \\
2016 & 534.191 & 352.924 \\
2017 & 485.690 & 275.469 \\
\hline \multicolumn{3}{l}{ Source: } \\
\multicolumn{2}{l}{ BPS Jawa Tengah $(2017)$}
\end{tabular}

Table 2 shows that aquaculture production in Central Java is always higher than capture fisheries production. Recognizing this potential, the government of Central Java began to design a policy program to develop the culture and fisheries subsector in Central Java. One of the programs is Bali Ndeso Mbangun Deso by establishing several districts and cities as minapolitan areas and Aquaculture fishery industrialization 2013 (Wibowo, 2015).

Aquaculture development and industrialization of Minapolitan area are based on the optimal utilization of potential resources and applying the principle of economic togetherness in aquaculture institutions, through the use of technology in production facilities, aquaculture processes, processing and marketing of commodities efficiently, by maintaining the preservation of natural resources and the environment (Pusdatik dan Informasi, 2013). There are 14 districts and cities in Central Java which then were considered as a minapolitan area and industrialization of fisheries. The following are production data and production value of aquaculture in minapolitan districs and cities: 
Table 3. Production and Production Value of Districs and Cities as Minapolitan Area in 2016

\begin{tabular}{lll}
\hline $\begin{array}{l}\text { Districs/ } \\
\text { Cities }\end{array}$ & $\begin{array}{l}\text { Productions } \\
\text { (tons) }\end{array}$ & $\begin{array}{l}\text { Value (million } \\
\text { rupiah) }\end{array}$ \\
\hline Banyumas & 9.967 & 352.513 .990 \\
Kab. & 4.320 & 73.587 .685 \\
Semarang & & 629.461 .500 \\
Klaten & 28.312 & 606.083 .685 \\
Boyolali & 33.027 & 40.937 .300 \\
Tegal & 1.874 & 583.395 .399 \\
Demak & 33.427 & 606.320 .645 \\
Pati & 42.037 & 261.843 .900 \\
Cilacap & 2.141 & 90.625 .940 \\
Purbalingga & 5.002 & 346.862 .305 \\
Magelang & 17.798 & 501.361 .095 \\
Brebes & 80.332 & 13.420 .790 \\
Kota Tegal & 753 & 22.742 .250 \\
Kota & $\mathbf{1 . 5 0 2}$ & 370.498 .000 \\
Pekalongan & & \\
Rembang & 7.193 & Tengah (2017) \\
\hline Source: BPS Jawa
\end{tabular}

Based on table 3 it is known that the highest aquaculture production is produced by Brebes Regency. Even though it has the highest production, the value of aquaculture production in Brebes Regency is still lower than other regencies whose production is much less. Regencies with higher production value than Brebes Regency with less production include Klaten Regency, Boyolali Regency, Demak Regency and Pati Regency. To find out the real production value, we look for the value of production per ton of minapolitan districts and cities:

Table 4 shows that the highest value of aquaculture production per ton is owned by Cilacap Regency, and the lowest production value per ton is owned by Brebes Regency. The low value of aquaculture production in Brebes
Regency with the highest production indicates that aquaculture production in Brebes Regency is not optimal. Therefore, there needs to be an effort to maximize the benefits of aquaculture production.

Table 4. Aquaculture Production Value per Tons in Districs/ Cities as Minapolitan Areas in 2016 (thousand rupiah)

\begin{tabular}{lll}
\hline Districs/ Cities & $\begin{array}{l}\text { Production } \\
\text { Tons }\end{array}$ & Value per \\
\hline Banyumas & 35.368 & \\
Kab. Semarang & 17.034 & \\
Klaten & 22.233 \\
Boyolali & 18.351 \\
Tegal & 21.845 \\
Demak & 17.453 \\
Pati & 14.423 \\
Cilacap & 122.300 \\
Purbalingga & 18.118 \\
Magelang & 19.489 \\
Brebes & 6.241 \\
Kota Tegal & 17.823 \\
Kota Pekalongan & 15.141 \\
Rembang & 51.508 \\
\hline
\end{tabular}

Source: Dinas Kelautan dan Perikanan (2017)

Brebes Subistrict is the subdistrict with the highest aquaculture production in Brebes Regency. Even in 2016 the number reached $76.39 \%$ of total production (BPS Kabupaten Brebes, 2017). Therefore, this subdistrict is the most prioritized area to be optimized for production, to realize the optimization of aquaculture production in Brebes Regency. Optimization of production is achieved by maximizing the profitability of aquaculture production through a combination of commodities produced. The aquaculture commodities cultivated in Brebes Subdistrict 
are vaname shrimp, tilapia, catfish, milkfish, and seaweed.

Based on the background of the problems that have been mentioned above, following are the research questions: 1 ) What is the mathematical model of optimization of aquaculture production that maximizes profits in Brebes Subdistrict? 2) What is the change interval that tolerates the acceptance of the aquaculture production optimization model in Brebes Subdistrict? 3) Is the production of aquaculture in Brebes Subdistrict factually maximizing profits compared to aquaculture production according to the model?

The objectives of this study are as follows: 1) To analyze mathematical models of optimization of aquaculture production that maximizes profits in Brebes Subdistrict. 2) To analyze the change interval that tolerates the acceptance of the production optimization model in Brebes Subdistrict. 3) To factually analyze aquaculture production in Brebes Subdistrict compared to aquaculture production according to the model.

Production is a process to combine, transform, and change inputs into outputs (Case \& Fair, 2007) that are called as producers. In economics theory, producers are considered as business units that have the same goal of achieving maximum profit. The most important example in analyzing the activities of producers is that producers will produce goods and services up to the number of goods and services that produce maximum profits. Furthermore, the main problem faced by producers in producing goods and services that achieve maximum profits is related to determining the combination of types and number of factors of production used (Sukirno, 2003).

The production function in economic activities is related to two things, namely to determine the maximum amount of output that might be produced based on the specific number of inputs used and to set the conditions for the minimum number of inputs used to produce a certain amount of output (Gaspersz, 200o). Producer behavior generally aims to maximize profits through maximizing production or minimizing production costs or competing with production optimization. Optimization is a normative approach by analyzing the best solution of a problem that occurs and then directed to the maximum or minimum point in a particular objective function (Nasendi \& Anwar, 1985). Mathematically, optimization of production can be known by conducting Linear Programming analysis.

According to Ruminta in (Saryoko, 2016) Linear Programming (PL) is an optimization calculation method with the aim of finding the optimum value consisting of the maximization and minimization of a linear objective function with various specific constraints. After knowing the combination of production that maximizes profits through Linear Programming analysis, there is a further analysis that needs to be done.

This analysis is called sensitivity, where the results can later be used as a reference optimization model which is formed is still relevant or not to be used if there is a change in the variables therein. With this analysis, the changes that might occur can be predicted and anticipated (Dewi, Tastrawati, \& Sari, 2014). Changes that might occur in the decision 
variable and constraint variable are the righthand side of the constraint function.

UU Number 45 Year 2009 Amendment to UU Number 31 Year 2009 concerning Fisheries states that fisheries are activities related to the management and utilization of fish resources and the environment starting from preproduction, production, processing, to marketing carried out in a fisheries business system. While aquaculture based on UU about Fisheries No. 45/2009 is defined as aquaculture activities which are a series of activities to maintain, grow and breed fishery commodities with a certain time of harvest with a controlled environment in such a way.

\section{METHOD}

This research is quantitative descriptive. Descriptive research is a research that provides a description of a subject or object systematically and scientifically, based on facts obtained when conducting research directly (Sanusi, 2014), while quantitative research is a research that processes data in the form of numbers (Misbahhudin \& Hasan, 2014). The data analysis method used in this study is a Linear Programming analysis to determine the combination of aquaculture production that produces maximum profits with limited resources available. Sensitivity analysis is also carried out to find out the change intervals that tolerate the acceptance of the optimization model.

This study uses primary and secondary data namely data that is already available and data obtained directly at the location of this research. The data is taken from the publication of several government agencies such as the DKP (Dinas Kelautan dan
Perikanan) of Central Java Province, BPS (Badan Pusat Statistik) of Central Java Province, and BPS of Brebes Districs. For the primary data obtained through interviews and observations. The data analysis tool in this study uses the POM for Windows 3.0 program.

The population in this study were aquaculture households in Brebes District, with a total sample of 93 FHs (Fishery Households) through the calculation of the Slovin formula.

Decision variables in this study explain the decision on the amount of certain aquaculture commodities to be produced along with the value of these commodities. Decision variables are as follows:

Table 5. Decision Variables

No. Decision Variables Symbol Unit

\begin{tabular}{|c|c|c|c|}
\hline 1 & $\begin{array}{l}\text { Vaname shrimp } \\
\text { production }\end{array}$ & $\mathrm{X}_{1}$ & $\mathrm{Kg}$ \\
\hline 2 & Tilapia productin & $\mathrm{X}_{2}$ & $\mathrm{Kg}$ \\
\hline 3 & Catfish production & $\mathrm{X}_{3}$ & $\mathrm{Kg}$ \\
\hline 4 & $\begin{array}{l}\text { Milkfish } \\
\text { production }\end{array}$ & $\mathrm{X}_{4}$ & $\mathrm{Kg}$ \\
\hline 5 & $\begin{array}{l}\text { Seaweed } \\
\text { production }\end{array}$ & $\mathrm{X}_{5}$ & $\mathrm{Kg}$ \\
\hline 6 & $\begin{array}{l}\text { Vaname shrimp } \\
\text { price }\end{array}$ & $\mathrm{P}_{1}$ & $\mathrm{Rp}$ \\
\hline 7 & Tilapia price & $\mathrm{P}_{2}$ & $\mathrm{Rp}$ \\
\hline 8 & Catfish price & $\mathrm{P}_{3}$ & $\mathrm{Rp}$ \\
\hline 9 & Milkfish price & $\mathrm{P}_{4}$ & $\mathrm{Rp}$ \\
\hline 10 & Seaweed price & $\mathrm{P}_{5}$ & $\mathrm{Rp}$ \\
\hline
\end{tabular}

Source: Data primer, (2019) processed

The constraint variables in this study explains the types of production factors and the number of production factors used to produce a combination of aquaculture 
commodities and the total number of available production factors. Production factors used in this study are land $\left(\mathrm{S}_{1}\right)$, seedlings $\left(\mathrm{S}_{2}\right)$, feed and fertilizer $\left(\mathrm{S}_{3}\right)$, and operational costs $\left(\mathrm{S}_{4}\right)$. In conducting Linear Programming analysis, there are two forming functions, namely the objective function and the constraint function as follows:

Objetive Fuctions:

$$
\begin{aligned}
& \mathrm{Z}=49.808_{p 1} \times X 1+16.500_{p 2} \times X 2+ \\
& 17.975_{p 3} \times X 3+16.435_{p 4} X 4+5.035_{p 5} \times
\end{aligned}
$$$$
X 5 \text {. }
$$

\section{Notes:}

$$
\begin{aligned}
\mathrm{Z}= & \text { total revenue/ profit } \\
\mathrm{P}_{1}= & \text { vaname shrimp price } \\
\mathrm{X}_{1}= & \text { the amount of vaname shrimp } \\
& \text { produced } \\
\mathrm{P}_{2}= & \text { tilapia price } \\
\mathrm{X}_{2}= & \text { the amount of tilapia produced } \\
\mathrm{P}_{3}= & \text { catfish price } \\
\mathrm{X}_{3}= & \text { the amount of catfish produced } \\
\mathrm{P}_{4}= & \text { milkfish price }
\end{aligned}
$$

$\mathrm{X}_{4}=$ the amount of milkfish produced

$\mathrm{P}_{5}=$ seaweed price/

$\mathrm{X}_{5}=$ the amount of seaweed produced

Constraint Fuctions:

$9,2 X 1+7 X 2+0,1 X 3+14,7 X 4+6,9 X 5 \leq$ 39.670 .000

$103 X 1+13 X 2+21 X 3+8 X 4+2 X 5 \leq$ 154.590 .525

$1,56 X 1+0.99 X 2+1,23 X 3+0,46 X 4+$ $0,04 X 5 \leq 4.473 .104$

$4.561 X 1+2171 X 2+1632 X 3+4096 X 4+$ $1.161 X \leq 14.261 .061 .304$

The left-hand side constraint function is the number of certain factors of production used to produce $1 \mathrm{~kg}$ of certain commodities. Meanwhile the right-hand side constraint function is the sum of all factors of certain production available for aquaculture activities.

\section{RESULTS AND DISCUSSION}

After analyzing the data, the discussion and further analysis of the results of the study are as follows:

Table 6. Optimization Prduction Analys Result of Aquaculture Production by POM for Windows 3.o Version

\begin{tabular}{llllllll}
\hline \multicolumn{7}{c}{ Optimasi Perikanan Budidaya Kec. Brebes Solution } \\
\hline & Shrimp & Tilapia & Catfish & Milkfish & Seaweed & RHS \\
\hline Maximize & 49.808 & 16.500 & 17.975 & 16.435 & 5.035 & & \\
Land & 9,2 & 7,0 & 0,1 & 14,7 & 6,9 & $<=$ & 39.670 .000 \\
Seeds & 103 & 13 & 21 & 8 & 2 & $<=$ & $154.321 .143,21$ \\
$\begin{array}{l}\text { Feed } \\
\text { Fertilizer }\end{array}$ & 1,56 & 0,99 & 1,23 & 0,46 & 0,04 & $<=$ & $4.473 .104,17$ \\
$\begin{array}{l}\text { Operational } \\
\text { Cosst }\end{array}$ & 4561,65 & 2171,46 & 1632,21 & 4096,82 & 1161,16 & $<=$ & 14.261 .061 .304 \\
Solution-> & $975.383,5$ & 0 & 1.985 .898 & $885.986,6$ & 2.532 .448 & & 111.590 .500 .000 \\
\hline
\end{tabular}

Source: Output POM for Windows (2019) processed 
The table above is a Linear Programming analysis by using the POM for Windows application, the analysis output with the aim of maximizing the benefits. It is known that the combination of aquaculture commodities that must be produced to achieve maximum profits in one cycle period is shown in the last line with the Solution description. Based on this line, the amount of each aquaculture commodity in the District of Brebes is:

a. Vaname Shrimp as much as $975 \cdot 383,5 \mathrm{~kg}$ with a production value of $\mathrm{Rp}$. 48.581.901.368.

b. Catfish as much as $1.985 .898 \mathrm{~kg}$ with a production value of Rp. 35.696.516.550.

c. Milkfish as much as $885.986,6 \mathrm{~kg}$ with a production value of Rp. 14.561.189.771.

d. Seaweed 2.532.448 kg with a production value of Rp. 12.750.875.680.

The combination of commodity production above resulted in a total revenue of Rp. 111,590,500,000 in one production cycle. The mathematical model of aquaculture production optimization obtained from the Linear Programming analysis is:

$$
\begin{aligned}
& Z=49.808_{p 1} \times 975.383,5_{x 1}+17.975_{p 3} \times \\
& 1.985 .898_{x 3}+16.435_{p 4} \times 885.986,6_{x 4}+ \\
& 5.035_{p 5} \times 2.532 .448_{x 5} \\
& Z=111.590 .500 .000
\end{aligned}
$$

In order the optimization model of aquaculture production in the Brebes District that is formed can be used, then the change in the selling price of vaname shrimp is not supposed to be less than Rp. $28.881,87$ and not more than Rp. 60.346,8; changes in the sale price of catfish not less than Rp. 17.102,47 and no more than Rp. 20.854,15; changes in milkfish prices not less than Rp. 15,431.84 and not more than Rp. 19.798,97; and changes in seaweed prices not less than Rp. 4.479,74 and not more than Rp. 5.496,69.

Production optimization model can still be used if the number of factors of production available for aquaculture activities in one production cycle is not less than $33.946 .780 \mathrm{~m} 2$ of cultivated land; the number of seedlings is not less than 79.158.430 heads/kg; the amount of feed and fertilizer is not less than 3.369.514 $\mathrm{kg}$ and not more than $5.432 .832 \mathrm{~kg}$; the total cost is not less than Rp. 13.226.800.00o. If the number of production factors available for aquaculture activities does not correspond to the minimum and maximum limits, then the optimization model of aquaculture production in the Brebes District must be re-established with the availability of new production factors.

To prove that aquaculture production in Brebes sub-district is not optimal, it can be done by comparing the number of aquaculture commodities produced and factual production profits with the results of the Linear Programming analysis in a one-year period. The intended production profit is the total production value and the production value per kilogram. 
Table 7. Comparison Between Linear Programmingming (LP) Result and Factual Production of Brebes Distric in 2018

\begin{tabular}{lll}
\hline \multicolumn{1}{c}{ Indicator } & \multicolumn{1}{c}{ LP Result } & \multicolumn{1}{c}{ Factual Production } \\
\hline Produksi Total $(\mathrm{kg})$ & 37.502 .231 & 58.423 .232 \\
Nilai Produksi Total (Rp) & 435.102 .650 .594 & 412.155 .662 .467 \\
Nilai Produksi per kg (Rp) & 11.602 & 7.055 \\
Produksi Tambak $(\mathrm{kg})$ & 5.673 .507 & 5.877 .203 \\
Produksi Kolam $(\mathrm{kg})$ & 3.971 .796 & $\mathbf{1 5 6 . 2 4 4}$ \\
Rumput Laut $(\mathrm{kg})$ & $\mathbf{2 7 . 8 5 6 . 9 2 8}$ & $5 \mathbf{2 . 3 8 9 . 7 8 4}$ \\
\hline
\end{tabular}

Source: Data Primer (2019) processed.

The results of the comparison prove that the production of aquaculture in the District of Brebes is not optimal because it does not provide maximum benefits. The value of production per $\mathrm{kg}$ of aquaculture in Brebes District is smaller than the value of production results from the Linear Programming analysis where the difference between the two reached $22,946,988,127$ rupiahs or $5 \cdot 57 \%$ greater. The value of production per ton of aquaculture in Brebes District is also factually lower compared to the results of the Linear Programming analysis.

\section{Combination of Aquaculture Production in Brebes Subdistrict}

Seaweed is the commodity with the highest amount that must be produced to achieve the optimal solution according to the results of the Linear Programming analysis. Generally, seaweed is one of the aquaculture commodities that are produced with very simple and traditional methods of aquaculture without the aid of any technology. Therefore, this commodity is in great demand by farmers who have limited capital (Priono, 2013).

In accordance with the conditions in the field where quite a lot of FHs cultivate seaweed. In addition, seaweed has a very easy aquaculture process with low production costs. In a one-year period, farmers only need to sow seeds once. After the first harvest, farmers do not need to sow seeds anymore and only take care to wait for the next harvest. Seaweed harvesting period is also the fastest which two months after seeding can be harvested. Then every once a month the seaweed can be harvested again without sowing the seeds again.

Various facilities obtained when cultivating seaweed certainly attracts FHs to produce this commodity in large quantities. However, based on the results of the Linear Programming, these commodities must be reduced in number to achieve maximum production benefits. This is because the value of seaweed is the lowest among other commodities, so it does not provide significant benefits. With the low profits derived from this commodity, it is expected that FHs are willing to reduce the amount of seaweed production and replace it with other more profitable commodities.

Shrimp is a commodity whose FHs are most commonly found in the field when researchers took the data. Based on the optimal solution from the results of the Linear Programming analysis, shrimp is the third 
largest commodity that must be produced. Although there are many shrimp farmers, the shrimp aquaculture process is quite complicated with many production facilities and infrastructure needed. In addition, shrimp production costs are also greater than the production of other commodities. Vaname shrimp harvesting period is fairly fast, where from the first stocking of seeds to harvesting time takes three months. After that, re-seeding is carried out to start the cultivation again.

There are two types of vaname shrimp cultivation methods used by FHs in Brebes sub-district, namely intensive and traditional pond methods. From observations conducted by researchers, intensive method costed more than traditional method. However, the results of research from Farionita (2018) stated that there were no significant differences between the two types of shrimp farming method. It is because, although the method is intensively more expensive the price of shrimp from this method is more expensive. Meanwhile, shrimp with traditional method with lower production costs have a more affordable selling price of shrimp. This means that the intensive and traditional method of Vaname shrimp cultivation in Brebes District have no economic difference.

Milkfish becomes the commodity that must be produced in the least amount based on the results of the Linear Programming analysis. Milkfish farmers are quite common in the District of Brebes. Milkfish is a commodity that is quite easily cultivated with traditional pond cultivation methods that are widely used by FHs. The disadvantage of milkfish when they are cultivated is the relatively long harvest period, which is 6 months after the seeding is spread. The problem of the slow growth of milkfish is also conveyed in Priono's research (2014). Even in the journal stated that the time to maintain milkfish reaches 8-10 months. Meanwhile, during that time, the size of milkfish has not been even and below $100 \mathrm{gr}$ per fish.

Although the care and feed of milkfish is not much, the long harvest time makes many farmers are less interested in raising milkfish. Moreover, the selling price of milk fish compared to other commodities is quite low.

Catfish commodities are cultivated in three villages, namely Tengki, Gandasuli, and Pasar Batang using biofloc or pond culture methods. Catfish become the aquaculture commodity with the second highest amount of production after seaweed according to the results of the Linear Programming analysis. Catfish cultivation is fairly easy because it is done in the yard and requires a land that is not too broad. For a land, usually consists of many ponds with different owners. Centralization of the cultivation place is done to facilitate cultivation activities and exchange experiences or find solutions if a problem is experienced by the cultivator. The deficiencies of the catfish cultivation is that it has a quite long harvest time, which is every six months. In addition, harvesting is done periodically and not all of them can be harvested at once.

The results of the Linear Programming analysis state that catfish are commodities whose production must be increased in large quantities. The huge demand for catfish for consumption makes this commodity very potential to provide high profits if cultivated. Considering the market absorption is also very high for catfish (Dwiyanto, 2014). With this in 
mind, FHs in Brebes District should be willing to increase catfish production in order to provide maximum benefits.

\section{Use of Production Factors in Brebes District}

The results of the sensitivity analysis using the POM for Windows application indicate the level of use of each production factor to produce aquaculture commodities that produce maximum profits is optimal. The level of use of each factor of production can be seen from the Constraint row and Slack/Surplus column where this column shows the number of factors of production remaining and not used in production activities. Following are the notes of the level of use of each factor in aquaculture production by obtaining maximum benefits:

a. Land is a limited or scarce resource, because the value of slack / surplus is o, meaning that the amount of available land is depleted in the optimal solution.

b. Seedlings are a limited or scarce resource, because the value of slack/surplus is $o$, meaning that the number of seeds available is depleted in the optimal solution.

c. Feed and fertilizer are limited or scarce resources, because the value of slack/surplus is o, meaning that the amount of feed and fertilizer available is depleted in the optimal solution.

d. Operating costs are a limited or scarce resource, because the value of slack / surplus is o, meaning that the total available operational costs are depleted in the optimal solution.

In accordance with the theory of production, that the producer is a unit that performs an activity with the aim of obtaining the highest profit (Sukirno, 2003). While the problem faced by producers in achieving maximum profit is the availability of limited production factors, so it is necessary to have a solution in allocating limited resources to produce goods and services that provide maximum benefits (Gilarso, 2003).

Based on sensitivity analysis in the optimization of aquaculture production in Brebes Subdistrict, the results of the analysis can realize the goal of a producer in obtaining the maximum benefit with the limitation of available production factors. Even in producing a combination of aquaculture commodity production that produces maximum profits, every available production factor is used entirely without any advantages or disadvantages. So it can be said that the results of the Linear Programming analysis and sensitivity analysis produce optimal production of aquaculture in the District of Brebes because the suggested production combination provides maximum benefits for the use of maximum production factors.

\section{Realization of Production Optimization}

The results of this study which is a combination of the production of aquaculture in the District of Brebes can be implemented significantly with the assumption that the FHs in the District of Brebes make groups based on the type of commodity being cultivated. The group in question is realized in the form of integrated fish cultivator institutions. Institutional is an appropriate place to implement the planning of aquaculture production in Brebes District.

The establisment of institutions will certainly provide various advantages and conveniences for FHs in producing aquaculture commodities in accordance with the optimization model. Institutions will provide an effect on increasing accelerated 
socio-economic development, facilitating the reach of capital, infrastructure, and markets, as well as expediting the process of technology adoption and innovation for members in it. In addition, the existence of institutional farmers will facilitate the government or related agencies to facilitate and provide strengthening for FHs (Anantanyu, 2011).

The results of this study are expected to be realized by the existence of a group of FHs that can provide benefits, both to the local government and individual FHs in Brebes District, Brebes Regency.

\section{CONCLUSION}

Based on the results of the research that has been carried out, the following conclusions can be drawn:

(1) The maximum benefit of aquaculture production in the District of Brebes can be obtained when the number of vaname shrimps produced is $975.383,5 \mathrm{~kg}$, catfish as much as $1.985 .898 \mathrm{~kg}$, milkfish as much as $885.986,6 \mathrm{~kg}$

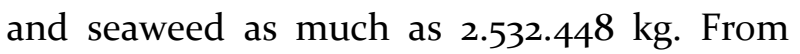
the combination of aquaculture production, it can be seen that the maximum amount of profit obtained is Rp. 111.590.500.00o for one cultivation cycle.

(2) Changes in commodity prices and availability of factors of production in aquaculture activities will not change the current production combination, as long as the amount is still within the tolerable change interval based on the results of sensitivity analysis. If changes occur beyond these intervals, a re-analysis must be carried out to find out the new production combination.

(3) Factual aquaculture production is not optimal because it does not produce maximum profits. This is indicated by the value of production per kilogram of Brebes district which is factually smaller than the value of production per kilogram of the results of the Linear Programming analysis which results in maximum profit for aquaculture in Brebes District.

Suggestions given related to the results of the study are:

This production optimization model can be implemented by local government, one of which is by strengthening household aquaculture institutions. The example is to form a cultivator group organization based on the type of commodity being cultivated. This is done so that the production target to be achieved for each commodity becomes a common goal.

The government is expected to provide direction and incentives to $\mathrm{FHs}$ related to achieving production combination targets that produce maximum profits. For example, by providing counseling and providing production facilities and infrastructure assistance for certain commodities that need to be increased in number. So that FHs are willing to produce these commodities.

In the future, it is hoped that the related offices can have a more complete database on the fisheries sector, so that the analysis carried out has accurate results. With the Kusuka program, this suggestion is certainly quite easy to be implemented. The database that can be added to the Kusuka information card is the production, type and use of production factors, commodity prices, and other important data.

\section{REFERENCES}

Badan Pusat Statistik. (2018). Statistik Sumber Daya Laut dan Pesisir. Jakarta: BPS Indonesia. 
Badan Pusat Statistik Jawa Tengah. (2017, Oktober 27). Perikanan Budidaya. Retrieved Juni 29, 2019, from Produksi Perikanan Budidaya Menurut Kabupaten/Kota Subsektor di Provinsi Jawa Tengah (ton), 2016:

https://jateng.bps.go.id/statictable/2017/10/27/1551/produ ksi-perikanan-budidaya-menurut-kabupatenkota-dan-subsektor-di-provinsi-jawa-tengah-ton2016.html

BPS Jaw Tengah. (2017). Provinsi Jawa Tengah Dalam Angka 2017. Semarang: CV. Jaya Luhur Makmur Abadi.

BPS Kabupaten Brebes. (2017). Kabupaten Brebes Dalam Angka Tahun 2017. Brebes: BPS Kabupaten Brebes.

Case, K. E., \& Fair, R. C. (2007). Prinsip-prinsip Ekonomi Jilid Satu Edisi Kedelapan. Jakarta: Erlangga.

Dewi, A. S., Tastrawati, N. T., \& Sari, K. (2014). Analisis Sensitivitas dalam Optimalisasi Keuntungan Produksi Busana dengan Metode Simpleks. Jurnal Matematika Vol 4 No 2, 1-12.

DKP Provinsi Jawa Tengah. (2017, April 26). DKP Prov. Jateng. Retrieved Juni 29, 2019, from Data Statistik Perikanan Budidaya (Nilai Produksi Perikanan Budidaya Menurut Jenis Budidaya Tahun 2016): https://dkp.jatengprov.

go.id/index.php/pengumuman/bidangbudidaya/d ata-statistik-perikanan-budida ya-menurut-jenisbudidaya-tahun-2016

Dwiyanto, B. S. (2014). Wirausaha Kelompok Usaha Budidaya Pembesaran Lele. Jurnal Maksipreneur Vol 4 No 1, 4-21.

Farionita, I. M., Aji, J. M., \& Supriono, A. (2018). Analisis Komparatif Usaha Budidaya Udang Vaname Tambak Tradisional dengan Tambak Intensif di Kabupaten Situbondo. Jurnal Ekonomi

Pertanian dan Agribisnis (JEPA) Vol 2 Nomor 4, 255-266.

Gaspersz, V. (200o). Ekonomi Manajerial Pembuatan Keputusan Bisnis. Jakarta: Gramedia Pustaka.

Gilarso, T. (2003). Pengantar Ilmu Ekonomi Mikro. Yogyakarta: Kanisius.

Haslan, R. (2018). Optimalisasi Produksi Kopi Bubuk Asli Lampung dengan Metode Simpleks (Studi Kasus
Industri Rumahan Kopi Bubuk Asli Lampung di Waydadi Kecamatan Sukamere Bandar Lampung). Skripsi, UIN Raden Intan Lampung: Bandar Lampung.

Kementerian Kelautan dan Perikanan RI. (2018). Produktifitas Perikanan Indonesia. Jakarta: Kementerian Kelautan dan Perikanan.

Keppres RI No.107 Tahun 2004 tentang Dewan Pengupahan. (2004).

Nasendi, B., \& Anwar, A. (1985). Program Linear dan Variasinya. Jakarta: Gramedia.

Prasetyo, P. E. (2009). Fundamental Makroekonomi. Yogyakarta: Beta Offset.

Priono, B. (2013). Budidaya Rumput Laut dalam Upaya Peningkatan Industrialisasi Perikanan. Media Akuakultur Volume 8 Nomor 1, 1-8.

Priono, B., Basuki, P. I., \& Kusnendar, E. (2014). Penggolongan Bandeng dengan Hasil Seleksi di Kabupaten Gresik Jawa Timur. Media Akuakultur Vol 9 No 1, 29-35.

Pusdatik dan Informasi. (2013). Profil Kelautan dan Perikanan Provinsi Jawa Tengah. Jakarta: Pusat data dan Statistik Informasi KKP.

Sanusi, A. (2014). Metodologi Penelitian Bisnis (Edisi 5 ed.). Jakarta: Salemba Empat.

Saryoko, A. (2016). Metode Simpleks dalam Optimalisasi Hasil Produksi. Informatics for Educators and Profesionals Vol 1 No 1, 27-36.

Sukirno, S. (2003). Pengantar Teori Mikroekonomi Edisi Ketiga. Jakarta: PT RajaGrafindo Persada.

Waite, R., Beveridge, M., Brummett, R., Castine, S., Chaiyawannakarn, N., Kaushik, S., et al. (2014). Improving Productivity and Enviromental Performance of Aquaculture. Installmen 5 of Creating a Sustainable Food Future, 2.

Wibowo, B. N. (2015). Efektivitas Kebijakan Bali Ndeso Mbangun Deso di Kabupaten Pekalongan (Studi Kasus Pelaksaan Bantuan Keuangan Pemerintah Jawa Tengah Kepada Pemerintah Desa tahun 2009-2012 dalam Bidang Pertanian di 3 Desa). Journal of Politic and Government Studies, Vol 4 No 2. 